\title{
EFFECT OF ARBUSCULAR MYCORRHIZAL FUNGI Glomus spp. INOCULATION ON ALFALFA GROWTH IN SOILS WITH COPPER
}

\author{
Daniela Novoa M. ${ }^{1}$, Soledad Palma S. ${ }^{1}$, and Hernán Gaete O. ${ }^{*}$
}

\begin{abstract}
Soils near mining centers usually have high heavy metal (HM) levels. It has been found that some plants associated with arbuscular mycorrhizal fungi (AMF) improve growth and tolerance to HM in soils. This symbiosis is a biological resource for degraded soil recovery. The objective of this study was to determine the effect of inoculating AMF (Glomus spp.) on alfalfa (Medicago sativa L.) growth in agricultural soils with different copper $(\mathrm{Cu})$ levels for degraded soil recovery. To this effect, alfalfa seeds were grown in soils from the Catemu and Casablanca valleys and inoculated with AMF. Plant height, stem diameter, and number of leaves were measured weekly. Dry matter, mycorrhizal colonization, and $\mathrm{Cu}$ concentration in alfalfa plant tissues were measured after 81 days. Inoculation increased plant height by $24 \%$, stem diameter by $11 \%$, and number of leaves by $34 \%$. Inoculation had a significant effect $(\mathrm{p} \leq 0.05)$ on alfalfa plants that were grown in soil with the highest $\mathrm{Cu}$ concentration, but had no effect on $\mathrm{Cu}$ accumulation in alfalfa plant tissues. A direct relationship was observed between $\mathrm{Cu}$ accumulation in alfalfa and $\mathrm{Cu}$ concentration in soils. It was concluded that alfalfa inoculated with Glomus spp. is applicable to the soil recovery process whenever soil properties can ensure inoculum effectiveness on alfalfa growth, and avoid toxicity by excessive $\mathrm{Cu}$ in alfalfa plant tissues.
\end{abstract}

Key words: Medicago sativa, mycorrhizal colonization, soil recovery.

\section{INTRODUCTION}

Copper $(\mathrm{Cu})$ mining is Chile's most important economic activity but also one of its major pollutants. The environmental problem provoked by this activity is related to soil contamination by heavy metals (HM), particularly $\mathrm{Cu}$ (De Gregori et al., 2003; Ávila et al., 2009). Although $\mathrm{Cu}$ is considered to be an essential nutrient for plants, it can be toxic in high concentrations (Lasat, 2000; Adriano, 2001; Ávila et al., 2009).

A plant community called metallophyte flora has developed specialized physiological mechanisms to survive in HM-rich soils (Ginocchio and Baker, 2004). Some tolerate HM in the soil by restricting absorption and/or translocation to their leaves, or act as indicators reflecting soil metal concentration in their tissues. Other species, however, show specialized mechanisms allowing them to accumulate or hyperaccumulate more

${ }^{1}$ Universidad de Valparaíso, Facultad de Ciencias, Av. Gran Bretaña 1111, Playa Ancha, Valparaíso, Chile. *Corresponding author (hernan.gaete@uv.cl).

Received: 25 March 2009.

Accepted: 03 July 2009. than $1000 \mathrm{mg} \mathrm{kg}^{-1} \mathrm{Cu}$ in their aerial biomass without showing any visible symptoms of toxicity (Lasat, 2000), but are characterized by their slow growth and scarce biomass due to energy used in adaptation mechanisms to high metal concentrations in their tissues (Citterio et al., 2005; Wang et al., 2007). This plant community is made up of a potentially valuable biological resource for the mining sector, for better closure and soil recovery practices of HM-enriched soils (Ginocchio and Baker, 2004). Lins et al. (2006) and Chen et al. (2007) point out that the use of vegetation to stabilize and control contamination would be the best way to recover minewaste impacted soils.

Plant metal absorption can be influenced by soil microorganisms or arbuscular mycorrhizal fungi (AMF) which are closely related to the plant roots (Citterio et al., 2005). The importance of this association lies in the fact that the plant transfers carbon products and energy derived from photosynthesis to the fungus, as well as an ecological niche. As regards the fungus, it helps plant growth and its capacity to supply water and nutrients, particularly phosphate and trace elements, obtained by its greater access to resources far from the root system (Chen et al., 2007; Jankong and Visoottiviseth, 2008). 
Leyval et al. (1997) and Lins et al. (2006) point out that AMF increase plant tolerance to HM in soils allowing its application in degraded soil recovery. However, the effect of AMF on HM tolerance and accumulation in plants depends on the type of AMF, species of host plant, type of HM, physical and chemical soil properties, and environmental conditions (Chen et al., 2007; Wang et al., 2007; Jankong and Visoottiviseth, 2008).

Jankong and Visoottiviseth (2008) worked with a commercial inoculum (Glomus spp. mixture) and distinct inoculated plants with results showing that the highest growth and metal absorption depends on the type of host plant. Wang et al. (2007) used corn (Zea mays L.) because it is mycotrophic-dependent with a high biomass, and can extract considerable quantities of $\mathrm{Pb}, \mathrm{Cd}$, and $\mathrm{Zn}$ from contaminated soils. However, it presented sensitivity to $\mathrm{Cu}$ when not translocating to the aerial tissue $\mathrm{Cu}$ absorbed from a moderately contaminated soil.

De Gregori et al. (2000) worked with alfalfa samples from the Puchuncaví and Catemu Valleys, Valparaíso Region, Chile. Their results show that when the level of $\mathrm{Cu}$ in the soils is higher, the capacity of alfalfa to accumulate it is greater. In turn, Peralta et al. (2004) demonstrated that alfalfa has the capacity to grow in $\mathrm{Cu}$-contaminated sites, and it is therefore feasible to use it to recover soils with sufficiently high $\mathrm{Cd}, \mathrm{Cu}$, or $\mathrm{Zn}$ concentrations, but do not impede seed germination.

The objective of this study was to determine the effect of arbuscular mycorrhizal fungi (Glomus spp.) inoculation on alfalfa growth in agricultural soils with distinct levels of $\mathrm{Cu}$ for degraded soil recovery.

\section{MATERIALS AND METHODS}

\section{Site selection and soil sampling}

Soil sampling was carried out between October and November 2007 in two agricultural zones of the Valparaíso Region, Chile. The first zone corresponds to the Catemu Valley located in the Aconcagua River valley. According to previous studies (De Gregori et al., 2000; 2003), this zone can be affected by particulate emissions containing $\mathrm{Cu}$ from the Chagres Foundry (32 $48^{\prime} \mathrm{S} 70^{\circ} 57^{\prime} \mathrm{W}$ ), which is why three sectors were sampled with different distances from the Foundry. The second zone corresponds to Casablanca Valley ( $\left.33^{\circ} 18^{\prime} \mathrm{S} 71^{\circ} 24^{\prime} \mathrm{W}\right)$. This zone is made up of an area without direct impact of $\mathrm{Cu}$ mining and metallurgical activities, and with edaphic and climatic characteristics similar to those in Catemu Valley (De Gregori et al., 2000; 2003).

In each sampled sector, $10 \mathrm{~kg}$ of soil was obtained from a depth between 0 and $20 \mathrm{~cm}$. Subsequently, soils were moved to the Environmental Biotechnology Laboratory of the Universidad de Valparaíso where they were passed through a 2-mm mesh sieve. Furthermore, soils were sterilized to avoid the presence of native mycorrhizal fungi and other microorganisms that could interfere with the experiment and alter measurements. Sterilization was carried out in an autoclave for $20 \mathrm{~min}$ on two consecutive days (Sadzawka, 1990).

\section{Physical and chemical soil analysis}

The physical and chemical soil sample analysis was carried out in the Soils and Foliar Analysis Laboratory of the Pontificia Universidad Católica de Valparaíso (Table 1). Granulometry and texture were determined by the simplified hydrometer method according to Sheldrick and Wang (1993). Percentage organic matter (OM) was obtained by the humid combustion method and colorimetric determination of reduced chromate (Sadzawka et al., 2006). The concentration of P (P-Olsen) was extracted with a $\mathrm{Na} 0.5 \mathrm{~mol} \mathrm{~L}^{-1}$ bicarbonate solution with $8.5 \mathrm{pH}$. Phosphorus in the extract was determined by colorimetry and molybdenum blue method, and with ascorbic acid as a reducer (Sadzawka et al., 2006). Furthermore, $\mathrm{pH}$ was measured with a digital $\mathrm{pH}$ meter (model Q-400M2, QUIMIS, Diadema, Sao Paulo, Brazil), and electrical conductivity with a digital conductivity meter (model SC-12, Suntex, Taipei, Taiwan), according to the methodology described by Jackson (1964).

Total $\mathrm{Cu}$ concentration was determined by atomicabsorption spectrophotometry with direct aspiration to the flame, then total digestion of the soils with nitric acid, hydrochloric acid, and peroxide (Sadzawka et al., 2005). Soluble $\mathrm{Cu}$ was determined with a $\mathrm{KNO}_{3} 0.1 \mathrm{M}$ solution as an extractor. The soluble $\mathrm{Cu}$ concentration was determined by atomic-absorption spectrophotometry (Sadzawka et al., 2005). Finally, the $\mathrm{Cu}^{+2}\left(\mathrm{pCu}^{+2}\right)$ free ion activity in the saturated paste extract (Sadzawka, 1990) was measured with a $\mathrm{Cu}$ ion-selective electrode (Sauvé et al., 1995; Rachou et al., 2007).

\section{Plants}

For this study, alfalfa 'California 55' was the variety recommended for Central Chile by ANASAC (Agrícola Nacional S.A.C.). Alfalfa is a mycotrophic-dependent legume. Its main characteristics are high biomass production, adaptation to different ecological regimes, and resistance to pests, diseases, and toxic elements (Tovar, 2006).

\section{Arbuscular mycorrhizal fungi (AMF) inoculum}

The inoculum applied was the commercial MYCOSYM TRI-TON ${ }^{\circledR}$ from MYCOSYM International AG Company which has a production plant in Málaga, Spain and commercial offices in Basel, Switzerland. The inoculum corresponds to a granular formulation product containing porous clay particles and fine roots with infection 
Table 1. Physical and chemical properties of soil samples.

\begin{tabular}{|c|c|c|c|c|}
\hline Properties & Soil 1 & Soil 2 & Soil 3 & Soil 4 \\
\hline \multicolumn{5}{|l|}{ Physical } \\
\hline Zone & Casablanca Valley & Catemu Valley & Catemu Valley & Catemu Valley \\
\hline Geographical coordinates & $33^{\circ} 18^{\prime} \mathrm{S} 71^{\circ} 24^{\prime} \mathrm{W}$ & $32^{\circ} 47^{\prime} \mathrm{S} 70^{\circ} 51^{\prime} \mathrm{W}$ & $32^{\circ} 47^{\prime} \mathrm{S} 70^{\circ} 57^{\prime} \mathrm{W}$ & $32^{\circ} 46^{\prime} \mathrm{S} 70^{\circ} 59^{\prime} \mathrm{W}$ \\
\hline Distance to foundry, $\mathrm{km}$ & nd & 13.5 & 1.2 & 4.3 \\
\hline Texture & Clay loam & Clay loam & Clay loam & Sandy clay loam \\
\hline \multicolumn{5}{|l|}{ Chemical } \\
\hline Initial pH & 5.93 & 7.38 & 7.71 & 7.07 \\
\hline Inoculated soil $\mathrm{pH}$ & 6.42 & 8.13 & 8.01 & 7.61 \\
\hline Non-inoculated soil $\mathrm{pH}$ & 5.57 & 7.28 & 6.83 & 6.64 \\
\hline Electrical conductivity, $\mathrm{S} \mathrm{m}^{-1}$ & 0.08 & 0.11 & 0.06 & 0.05 \\
\hline Organic matter, $\%$ & 3.35 & 3.36 & 3.17 & 4.47 \\
\hline P-Olsen, $\mathrm{mg} \mathrm{kg}^{-1}$ & 31.8 & 53.6 & 48.1 & 18.3 \\
\hline Total $\mathrm{Cu}, \mathrm{mg} \mathrm{kg}^{-1}$ & 53.8 & 96.4 & 128 & 620 \\
\hline Soluble $\mathrm{Cu}, \mathrm{mg} \mathrm{kg}^{-1}$ & 0.09 & 0.04 & 0.37 & 0.71 \\
\hline $\mathrm{pCu}^{+2}$ & 13.2 & 14.6 & 12.8 & 13.3 \\
\hline
\end{tabular}

nd: not determined. $\mathrm{pCu}^{+2}:-\log \left(\mathrm{Cu}^{+2}\right.$ free ion activity).

units (spores and hyphae) of Glomus etunicatum, $G$. intraradices, and G. fasciculatum fungi.

\section{Experimental design}

A bifactorial $4 \times 2$ design was carried out for sowing with four soil samples and two treatments for each sample: inoculated with AMF and non-inoculated. Each treatment had four experimental units. Thirty-two 1-kg capacity plastic pots were used. To each experimental unit in the inoculated treatment, $500 \mathrm{~g}$ of the respective soil sample and $15 \mathrm{~g}$ of inoculum were added, 30 alfalfa seeds were homogeneously scattered on the surface, and then covered with $300 \mathrm{~g}$ of soil sample. To each experimental unit in the non-inoculated treatment, $500 \mathrm{~g}$ of the respective soil sample was added and 30 alfalfa seeds were covered with $300 \mathrm{~g}$ of soil sample. The experiment was carried out between December 2007 and February 2008 . Plants grew in greenhouse conditions at environmental temperature $\left(17^{\circ} \mathrm{C}\right.$ mean $), 50 \%$ air relative humidity, and photoperiod 14:10 h. Plants were irrigated every $2 \mathrm{~d}$ with $22 \mathrm{~mL}$ of potable water (Ginocchio and Narváez, 2002). Plant height, stem diameter, and number of leaves were measured once a week throughout the experiment.

\section{Plant analysis}

Alfalfa plants were harvested after $81 \mathrm{~d}$ of growth. Plants were washed in hydrochloric acid $0.01 \mathrm{~N}$, distilled water, EDTA $0.05 \mathrm{M}$, and once again with distilled water (Ginocchio et al., 2002). Subsequently, biomass (dry weight) was determined by separating aerial (leaves and stem) and root tissues of the harvested plants. These were placed in a drying oven (model LDO-150N, Labtech Hebro, Santiago, Chile) at $60^{\circ} \mathrm{C}$ for $48 \mathrm{~h}$, and then weighed (Ginocchio and Narváez, 2002). To determine mycorrhizal colonization, a $1 \mathrm{~cm}$ fragment of undried alfalfa root was separated, classified in $\mathrm{KOH} 2.5 \% \mathrm{p} / \mathrm{v}$ for $3 \mathrm{~d}$, then left in $\mathrm{HCl} 1 \%$ for $1 \mathrm{~d}$ to eliminate excess $\mathrm{KOH}$, and finally stained with trypane blue $0.05 \% \mathrm{p} / \mathrm{v}$ (Phillips and Hayman, 1970). The stained roots were randomly distributed in a squared Petri dish and the percentage of mycorrhizal colonization was counted with a stereoscopic microscope (model Stemi DV4, Zeiss, New York, USA) in accordance with the line intercept method (Giovanetti and Mosse, 1980).

The concentration of $\mathrm{Cu}$ in alfalfa aerial and root tissues in the presence and absence of mycorrhizae was obtained by atomic-absorption spectrophotometry with an air-acetylene flame for direct aspiration (model 902, GBC, Melbourne, Australia), and dried and ground samples of plant tissue were then transferred to Teflon containers for digestion with nitric acid, peroxide, and hydrofluoric acid according to the description in Sadzawka et al. (2007).

The bioconcentration factor $(\mathrm{BF})$ corresponds to the plant's ability to capture and transport metals from the soil to its tissues. This factor was obtained by dividing total plant $\mathrm{Cu}$ concentration (aerial and root) by soil total $\mathrm{Cu}$ concentration (McGrath and Zhao, 2003). The translocation factor (TF) corresponds to the plant's ability to transport the metal from the root to the aerial tissue, and was obtained by 
dividing $\mathrm{Cu}$ concentration in the plant aerial tissue by $\mathrm{Cu}$ concentration in the root tissue (Wang et al., 2007).

\section{Statistical analysis}

One factor was analyzed by ANOVA and followed by multiple comparisons Tukey test with $5 \%$ probability to determine the statistically significant differences between inoculated and non-inoculated treatments. Pearson linear correlations were applied to the variables analyzed in the plants and soil $\mathrm{Cu}$ concentrations. These analyses were done by the statistical program Minitab 15 (Minitab, State College, Pennsylvania, USA). Results having more than one replicate are shown as mean \pm standard deviation.

\section{RESULTS AND DISCUSSION}

The soil sample from the Casablanca Valley showed the lowest total $\mathrm{Cu}$ concentration while soil samples from the Catemu Valley showed the highest concentrations (Table 1). High $\mathrm{Cu}$ concentrations in Catemu Valley are explained mostly by mining activity, while the variation in the concentration is explained by the distance to the copper foundry. Soil $\mathrm{Cu}$ levels in this study are higher than those reported by De Gregori et al. (2000) in the same sectors. Soluble $\mathrm{Cu}$ concentrations were in the range of 0.09 and $0.71 \mathrm{mg} \mathrm{kg}^{-1}$ and directly related to total $\mathrm{Cu}$ concentrations $(r=0.92 ; p>0.05)$, for this reason soils were identified according to total $\mathrm{Cu}$ concentration.

\section{Mycorrhizal colonization}

Soil $\mathrm{pH}$ in inoculated treatments increased significantly $(\mathrm{p} \leq 0.05)$, and it was not significant $(\mathrm{r}=0.74 ; \mathrm{p}>0.05)$ even when there was a relationship with mycorrhizal colonization (Table 1). On this subject, Lins et al. (2007) point out that $\mathrm{pH}$ can influence mycorrhizal colonization since fungi of the Glomus genus are mostly found in soils with $\mathrm{pH}$ equal or greater than 6.1 .

It can be observed in Figure 1 that AMF inoculum colonized alfalfa roots in four soils. The highest

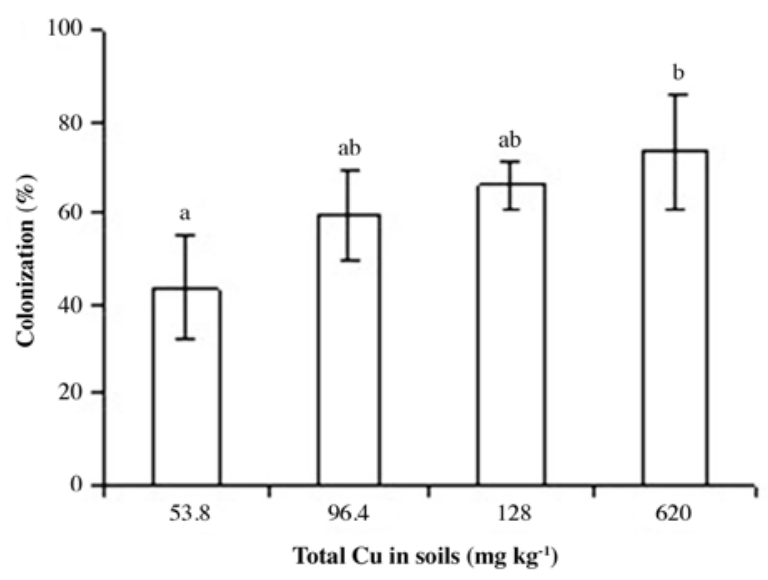

Different letters indicate significant differences among treatment according to Tukey test $(\mathrm{p} \leq 0.05)$.

Figure 1. Percentage of mycorrhizal colonization (mean $\pm \mathrm{SD}$ ) in inoculated alfalfa roots for different soil $\mathrm{Cu}$ concentrations.

Table 2. Comparison of arbuscular mycorrhizal fungi inoculated and non-inoculated treatments for growth parameters of alfalfa plants: plant height, stem diameter, number of leaves, shoot and root dry matter after $81 \mathrm{~d}$ of growth in soils with increasing $\mathrm{Cu}$ concentrations.

\begin{tabular}{|c|c|c|c|c|}
\hline & \multicolumn{4}{|c|}{ Total $\mathrm{Cu}$ in soils } \\
\hline & 53.8 & 96.4 & 128 & 620 \\
\hline & 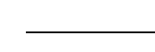 & - & & - \\
\hline \multicolumn{5}{|l|}{ Plant height, $\mathrm{cm}$} \\
\hline Inoculated & $34 \pm 3.5$ & $31.8 \pm 2.5^{*}$ & $35.1 \pm 8.5$ & $25.9 \pm 8 *$ \\
\hline Non-inoculated & $29 \pm 9.1$ & $24.5 \pm 5.1$ & $27.4 \pm 2$ & $15.4 \pm 2.2$ \\
\hline \multicolumn{5}{|c|}{ Stem diameter, mm } \\
\hline Inoculated & $2 \pm 0.3$ & $2 \pm 0.1 *$ & $2 \pm 0.1$ & $1 \pm 0.3 *$ \\
\hline Non-inoculated & $1.9 \pm 0.3$ & $1.6 \pm 0.3$ & $1.9 \pm 0.3$ & $1 \pm 0.1$ \\
\hline \multicolumn{5}{|l|}{ Number of leaves } \\
\hline Inoculated & $109 \pm 35^{*}$ & $59 \pm 6$ & $71 \pm 5$ & $44 \pm 5^{* *}$ \\
\hline Non-inoculated & $61 \pm 20$ & $48 \pm 13$ & $63 \pm 9$ & $16 \pm 2$ \\
\hline \multicolumn{5}{|l|}{ Aerial biomass, $\mathrm{g}$} \\
\hline Inoculated & $2.9 \pm 0.8$ & $2.2 \pm 0.3$ & $2.3 \pm 0.3$ & $1.1 \pm 0.3$ \\
\hline Non-inoculated & $2.2 \pm 1.4$ & $1.6 \pm 0.9$ & $1.9 \pm 0.3$ & $0.9 \pm 0.7$ \\
\hline \multicolumn{5}{|l|}{ Root biomass, $\mathrm{g}$} \\
\hline Inoculated & $1.1 \pm 0.6$ & $0.3 \pm 0.2$ & $0.7 \pm 0.3$ & $0.6 \pm 0.5$ \\
\hline Non-inoculated & $1.1 \pm 0.8$ & $0.4 \pm 0.3$ & $0.4 \pm 0.2$ & $0.3 \pm 0.2$ \\
\hline
\end{tabular}

$* \mathrm{p} \leq 0.05 ; * * \mathrm{p} \leq 0.01$. Difference between inoculated and non-inoculated treatment according to ANOVA. Mean \pm SD is indicated. 
colonization percentage $(73.6 \%)$ was in the soil with the highest $\mathrm{Cu}$ concentration $\left(620 \mathrm{mg} \mathrm{kg}^{-1}\right)$. This demonstrates Glomus spp. inoculum tolerance to $\mathrm{Cu}$ concentrations present in soils.

\section{Alfalfa growth}

Whether the treatment was inoculated or non-inoculated, growth of plants cultivated in the soil with the highest $\mathrm{Cu}$ concentration $\left(620 \mathrm{mg} \mathrm{kg}^{-1}\right)$ was significantly lower $(\mathrm{p} \leq$ $0.05)$ than growth of plants cultivated in soils with lower $\mathrm{Cu}$ concentrations (Table 2).

Comparing treatments, plant height was on the average $24 \%$ higher, stem diameter $11 \%$ higher, and number of leaves $34 \%$ higher in the inoculated treatments. This difference between treatments was significant when alfalfa plants were cultivated in soil with a higher $\mathrm{Cu}$ concentration (Table 2). Results were similar to those reported by Lins et al. (2006) in Leucaena leucocephala (Lam.) plants. In their study, they inoculated plants with AMF Glomus etunicatum, and those cultivated in soil with higher $\mathrm{Cu}$ concentration showed a higher height and number of leaves than non-inoculated plants.

As regards biomass (dry weight), independently of the treatment, alfalfa plants cultivated in soil with the lowest $\mathrm{Cu}$ concentration $\left(53.8 \mathrm{mg} \mathrm{kg}^{-1}\right)$ had a significantly higher ( $\mathrm{p} \leq 0.05$ ) aerial and root biomass than plants cultivated in soils with the highest $\mathrm{Cu}$ concentration $\left(620 \mathrm{mg} \mathrm{kg}^{-1}\right)$ (Table 2). Alfalfa plant aerial and root biomass was 23 and $19 \%$ higher in the inoculated treatments, respectively, though this difference was not significant $(p>0.05)$. This is similar to what Citterio et al. (2005) found in Cannabis sativa L. plants inoculated with AMF Glomus mosseae cultivated in soils contaminated with HM and where there was no significant difference between the biomass of plants inoculated with AMF and those non-inoculated.

\section{Accumulation of $\mathrm{Cu}$ in alfalfa}

Copper concentrations in alfalfa aerial tissues are in the 20 to $100 \mathrm{mg} \mathrm{kg}^{-1}$ range (Table 3), corresponding to excessive or toxic concentrations for agricultural crops (Adriano, 2001). Chlorosis in the leaves of alfalfa plants cultivated in soil with a higher $\mathrm{Cu}$ concentration appeared after $25 \mathrm{~d}$ of growth. Chlorosis continued until the plants were harvested without killing them. Ginocchio and Narváez (2002) point out that when the tolerance to excess $\mathrm{Cu}$ accumulated in the roots is surpassed, translocation of this element to the shoot takes place affecting photosynthesis and other cell functions. Peralta et al. (2004) point out that HM reduce plant aerial tissue growth which decreases chlorophyll content and photosystem I activity. This would have originated chlorosis and lower aerial tissue growth of plants sown in the soil with the highest $\mathrm{Cu}$ concentration.

There was generally no significant difference between $\mathrm{Cu}$ accumulation in alfalfa plants inoculated with Glomus spp. and those non-inoculated. Except for the plants sown in the soil with the lowest $\mathrm{Cu}$ concentration, alfalfa plants accumulated a higher $\mathrm{Cu}$ concentration in root tissue than in aerial tissue (Table 3 ). These results are similar to those reported by Lins et al. (2006) working with Leucaena leucocephala (Lam.) plants inoculated with AMF Glomus etunicatum.

Copper accumulation in alfalfa aerial and root tissue in the inoculated, as well as the non-inoculated treatment, had a direct relationship with soil total $\mathrm{Cu}$ concentration (Table 3). There is a tendency toward higher $\mathrm{Cu}$ accumulation in alfalfa tissues when soil $\mathrm{Cu}$ concentration increases. The results of this study coincide with results obtained by De Gregori et al. (2000) where

Table 3. Comparison of arbuscular mycorrhizal fungi inoculated and non-inoculated treatments for Cu concentration in alfalfa plant shoot and root tissues expressed as dry weight. Pearson correlations between Cu concentration in alfalfa and $\mathrm{Cu}$ concentration in soils and their significance levels are shown.

Total $\mathrm{Cu}$ in soils

\begin{tabular}{|c|c|c|c|c|c|c|c|}
\hline & Treatment & 53.8 & 96.4 & 128 & 620 & $\mathbf{R}$ & $\mathbf{P}$ \\
\hline \multirow{2}{*}{\multicolumn{8}{|c|}{$\mathrm{Cu}$ in alfalfa }} \\
\hline & & & & & & & \\
\hline \multirow[t]{2}{*}{ Aerial } & Inoculated & $39.5 \pm 2.5^{*}$ & $25.3 \pm 0.3$ & $34.1 \pm 7.5$ & $79.7 \pm 24.2$ & 0.95 & 0.04 \\
\hline & Non-inoculated & $48.2 \pm 1.2$ & $25.7 \pm 3.5$ & $31.7 \pm 5.3$ & $75.9 \pm 6.4$ & 0.86 & 0.14 \\
\hline \multirow[t]{2}{*}{ Root } & Inoculated & $27.7 \pm 3$ & $33.6 \pm 0.8^{* *}$ & $51.8 \pm 1$ & $170^{1}$ & 0.99 & 0.002 \\
\hline & Non-inoculated & $19.5 \pm 3.6$ & $38.9 \pm 0.1$ & $47.4 \pm 13.4$ & $226^{1}$ & 0.99 & 0.001 \\
\hline \multirow[t]{2}{*}{$\mathrm{BF}$} & Inoculated & $1.2 \pm 0.06$ & $0.6 \pm 0.01 * *$ & $0.7 \pm 0.05$ & $0.4 \pm 0.04$ & -0.71 & 0.30 \\
\hline & Non-inoculated & $1.3 \pm 0.06$ & $0.7 \pm 0.04$ & $0.6 \pm 0.1$ & $0.5 \pm 0.01$ & -0.6 & 0.34 \\
\hline \multirow[t]{2}{*}{$\mathrm{TF}$} & Inoculated & $1.4 \pm 0.07$ & $0.8 \pm 0.03$ & $0.7 \pm 0.13$ & $0.5 \pm 0.14$ & -0.69 & 0.31 \\
\hline & Non-inoculated & $2.5 \pm 0.53$ & $0.7 \pm 0.09$ & $0.7 \pm 0.31$ & $0.3 \pm 0.03$ & -0.6 & 0.41 \\
\hline
\end{tabular}

$* \mathrm{p} \leq 0.05 ; * * \mathrm{p} \leq 0.01$. Difference among treatments according to ANOVA. Mean \pm SD is indicated.

${ }^{1}$ Only one value; BF: bioconcentration factor. TF: translocation factor. 
alfalfa plants from the Puchuncaví and Catemu valleys tended to accumulate a greater quantity of $\mathrm{Cu}$ in their tissues when soil $\mathrm{Cu}$ levels increased. Likewise, Wang et al. (2007) reported that in corn plants inoculated with AMF Acaulospora mellea, $\mathrm{Cu}$ concentration in the roots tended to increase when soil $\mathrm{Cu}$ levels increased, whether the treatment was inoculated or non-inoculated.

Bioconcentration (BF) and translocation (TF) factors (Table 3) tend to decrease when soil $\mathrm{Cu}$ concentration increases. Alfalfa plants cultivated in the soil with the lowest $\mathrm{Cu}$ concentration showed higher $\mathrm{BF}$ and $\mathrm{TF}$ values, whereas alfalfa plants cultivated in the soil with the highest $\mathrm{Cu}$ concentration had lower BF and TF values. This behavior indicates the beneficial effect of mycorrhizal colonization under excessive HM conditions where AMF acts as a protective barrier restricting soil metal transfer to the plant and the subsequent metal translocation from the root to aerial tissue (Wang et al., 2007; Jankong and Visoottiviseth, 2008).

\section{CONCLUSIONS}

Arbuscular mycorrhizal inoculum (Glomus spp.) tolerated $\mathrm{Cu}$ concentrations in the soil samples from the Catemu and Casablanca valleys. Inoculation had a beneficial effect on alfalfa growth in soils with $\mathrm{Cu}$, but not on tissue $\mathrm{Cu}$ accumulation. There was a tendency for alfalfa to accumulate a greater quantity of $\mathrm{Cu}$ in its root and aerial tissues when soil $\mathrm{Cu}$ concentration increased. These results suggest the potential use of alfalfa inoculated with mycorrhizal fungi (Glomus spp.) in $\mathrm{Cu}$-degraded soil recovery processes. However, to apply this, associated costs and soil properties must be considered, such as the quantity of $\mathrm{Cu}$, in order to ensure inoculum effectiveness on alfalfa growth and avoid toxicity symptoms in the plants as a result of excessive $\mathrm{Cu}$ accumulation in their tissues

\section{ACKNOWLEDGEMENTS}

This study was funded by the projects: Dipuv 49/2007 and CIGREN Dipuv 01/2003 of the Research Direction of the Universidad de Valparaíso.

\section{RESUMEN}

Efecto de la inoculación con hongos micorrízicos arbusculares Glomus spp.sobre el crecimiento de alfalfa en suelos con cobre. Los suelos cercanos a centros de actividad minera suelen presentar altos niveles de metales pesados (HM). Se ha encontrado que algunas plantas asociadas a hongos micorrízicos arbusculares (AMF) mejoran su crecimiento y tolerancia a los HM presentes en los suelos. Esta simbiosis constituye un recurso biológico para la recuperación de suelos degradados. El objetivo de este estudio fue determinar el efecto de la inoculación con AMF (Glomus spp.) sobre el crecimiento de alfalfa (Medicago sativa L.) en suelos agrícolas con distintos niveles de cobre $(\mathrm{Cu})$ para la recuperación de suelos degradados. Para ello se sembraron semillas de alfalfa en suelos del Valle de Catemu y Casablanca y se inocularon con AMF. Semanalmente se midió la altura de las plantas, diámetro de tallo y número de hojas. Transcurridos 81 días se determinó biomasa, colonización micorrízica y concentración de $\mathrm{Cu}$. La inoculación incrementó un $24 \%$ la altura de la planta, $11 \%$ el diámetro del tallo y $34 \%$ el número de hojas. La inoculación tuvo un efecto significativo $(\mathrm{p} \leq 0.05)$ sobre el crecimiento de alfalfa en el suelo con mayor concentración de $\mathrm{Cu}$, pero no sobre la acumulación de $\mathrm{Cu}$ en sus tejidos. La acumulación de $\mathrm{Cu}$ en alfalfa se relacionó directamente con la concentración de $\mathrm{Cu}$ en los suelos. Se concluye que alfalfa inoculada con Glomus spp. es aplicable a procesos de recuperación de suelos, siempre que se consideren las propiedades del suelo para asegurar la efectividad del inóculo sobre el crecimiento de alfalfa y evitar la toxicidad por exceso de $\mathrm{Cu}$ en sus tejidos.

Palabras clave: Medicago sativa L., colonización micorrízica, recuperación de suelos.

\section{LITERATURE CITED}

Adriano, D.C. 2001. Trace elements in terrestrial environments: Biogeochemistry, bioavailability, and risk of metals. 866 p. $2^{\text {a }}$ ed. Springer-Verlag, New York, USA.

Ávila, G., H. Gaete, S. Sauvé, and A. Neaman. 2009. Organic matter reduces copper toxicity for the earthworm Eisenia fetida in soils from mining areas in central Chile. Chilean J. Agric. Res. 69:252-259.

Chen, B., Y. Zhu, J. Duan, X. Xiao, and S. Smith. 2007. Effects of the arbuscular mycorrhizal fungus Glomus mosseae on growth and metal uptake by four plant species in copper mine tailings. Environ. Pollut. 147:374-380.

Citterio, S., N. Prato, P. Fumagalli, R. Aina, N. Massa, A. Santagostino, et al. 2005. The arbuscular mycorrhizal fungus Glomus mosseae induces growth and metal accumulation changes in Cannabis sativa $\mathrm{L}$. Chemosphere 59:21-29.

De Gregori, I., E. Fuentes, M. Rojas, H. Pinochet, and M. Potin. 2003. Monitoring of copper, arsenic and antimony levels in agricultural soils impacted and non-impacted by mining activities, from three regions in Chile. J. Environ. Monitor. 5:287-295. 
De Gregori, I., G. Lobos, S. Lobos, H. Pinochet, M. Potin, and M. Astruc. 2000. Copper and selenium in rainwater, soils and alfalfa from agricultural ecosystems of Valparaíso Región, Chile. Bol. Soc. Chil. Quím. 45(1):131-146.

Ginocchio, R., and A. Baker. 2004. Metallophytes in Latin America: A remarkable biological and genetic resource scarcely known and studied in the region. Rev. Chil. Hist. Nat. 77:185-194.

Ginocchio, R., y J. Narváez. 2002. Importancia de la forma química y de la matriz del sustrato en la toxicidad por cobre en Noticastrum sericeum (Less.) Less. Ex Phil. Rev. Chil. Hist. Nat. 75:603-612.

Ginocchio, R., I. Toro, D. Schnepf, and M.R. Macnair. 2002. Copper tolerance testing in populations of Mimulus luteus var. variegatus exposed and nonexposed to copper mine pollution. Geochem. Explor. Environ. Anal. 2(2):151-156.

Giovanetti, M., and B. Mosse. 1980. An evaluation of techniques for measuring vesicular-arbuscular mycorrhizal infection in roots. New Phytol. 84:489500 .

Jackson, M.L. 1964. Análisis químico de suelos. 633 p. Ediciones Omega, Barcelona, España.

Jankong, P., and P. Visoottiviseth. 2008. Effects of arbuscular mycorrhizal inoculation on plants growing on arsenic contaminated soil. Chemosphere 72:10921097.

Lasat, M. 2000. The use of plants for the removal of toxic metals from contaminated soil. $33 \mathrm{p}$. American Association for the Advancement of Science, Environmental Science and Engineering Fellow, Washington, D.C., USA.

Leyval, C., K. Turnau, and K. Haselwandter. 1997. Effect of heavy metal pollution on mycorrhizal colonization and function: physiological, ecological and applied aspects. Mycorrhiza 7:139-153.

Lins, C.E.L., U.M.T. Cavalcante, E.V.S.B. Sampaio, A.S. Messias, and L.C. Maia. 2006. Growth of mycorrhized seedlings of Leucaena leucocephala (Lam.) de Wit. in a copper contaminated soil. Appl. Soil Ecol. 31:181185.

Lins, C.E.L., L.C. Maia, U.M.T. Cavalcante, and E.V.S.B. Sampaio. 2007. Efeito de fungos micorrízicos arbusculares no crescimento de mudas de Leucaena leucocephala (Lam.) de Wit. em solos de Caatinga sob impacto de mineração de cobre. R. Árvore (Viçosa) 31(2):355-363.

McGrath, S., and F. Zhao. 2003. Phytoextraction of metals and metalloids from contaminated soils. Curr. Opin. Biotechnol. 14:277-282.
Peralta, J., G. De la Rosa, J. González, and J. Gardea. 2004. Effects of the growth stage on the heavy metal tolerance of alfalfa plants. Adv. Environ. Res. 8:679685.

Phillips, J., and D. Hayman. 1970. Improved procedure for clearing roots and staining parasitic and vesiculararbuscular mycorrhizal fungi for rapid assessment of infection. Trans. Br. Mycol. Soc. 55:158-161.

Rachou, J., C. Gagnon, and S. Sauvé. 2007. Use of an ionselective electrode for free copper measurements in low salinity and low ionic strength matrices. Environ. Chem. 4(2):90-97.

Sadzawka, A. 1990. Métodos de análisis de suelos. Serie La Platina $\mathrm{N}^{\circ} 16.130$ p. Instituto de Investigaciones Agropecuarias, Centro Regional de Investigación La Platina, Santiago, Chile.

Sadzawka, A., M. Carrasco, R. Demanet, H. Flores, R. Grez, M. Mora, y A. Neaman. 2007. Métodos de análisis de tejidos vegetales. $2^{\mathrm{a}}$ ed. Serie actas INIA N ${ }^{\circ}$ 40. 53 p. Instituto de Investigaciones Agropecuarias, Centro Regional de Investigación La Platina, Santiago, Chile.

Sadzawka, A., M. Carrasco, R. Grez, y M. Mora. 2005. Métodos de análisis de compost. Serie Actas INIA N ${ }^{\circ}$ 30. 142 p. Instituto de Investigaciones Agropecuarias, Centro Regional de Investigación La Platina, Santiago, Chile.

Sadzawka,A., M. Carrasco, R. Grez, M. Mora, H.Flores, y A. Neaman. 2006. Métodos de análisis recomendados para los suelos de Chile. Serie Actas INIA N ${ }^{\circ} 34.164$ p. Instituto de Investigaciones Agropecuarias, Centro Regional de Investigación La Platina, Santiago, Chile.

Sauvé, S., M. McBride, and W. Hendershot. 1995. Ionselective electrode measurements of copper(II) activity in contaminated soils. Arch. Environ. Contam. Toxicol. 29(3):373-379.

Sheldrick, B., and C. Wang. 1993. Particle size distribution. p. 499-511. In Carter, M. (ed.) Soil sampling and methods of analysis. Canadian Society of Soil Science. Lewis Publishers, Boca Ratón, Florida, USA.

Tovar, J. 2006. Selección en invernadero de inóculos de micorriza arbuscular (MA) para el establecimiento de la alfalfa en un Andisol de la Sabana de Bogotá. Universitas Scientiarum 11:87-103.

Wang, F., X. Lin, and R. Yin. 2007. Inoculation with arbuscular mycorrhizal fungus Acaulospora mellea decreases $\mathrm{Cu}$ phytoextraction by maize from $\mathrm{Cu}-$ contaminated soil. Pedobiologia 51:99-109. 